\title{
The Strategy of Realizing Sharia Based School Cooperative in Tasikmalaya City, Indonesia
}

\author{
Asep Suryanto 1 \\ 1/slamic Economic Studies Program, Faculty of Islamic Studies, \\ Siliwangi University Tasikmalaya, West Java, Indonesia. \\ Email: a_suryanto72@yahoo.co.id
}

\begin{abstract}
:
The objectives of this research: 1) what factors become a problem so that school cooperative still not become sharia based school cooperative? 2) How is the strategy to realize sharia cooperative in school? This research used a qualitative approach, i.e., Analytic Network Process (ANP). In applying the ANP method, the researcher does the following: 1) structuring the hierarchical complexity into the homogeneous clusters of the factors, 2) performing the measurements into the ratio scale at all the lowest levels of the hierarchy/ network, 3) synthesizing. Data used in this research is primary data collected from questionnaires and in depth interview with experts, the policy holder, students, and teacher coach. The results of the research show that 1) The factors that become the problem of difficulties in realizing sharia-based school cooperatives are less student participation, limited capital and infrastructure, knowledge of sharia co-operatives that are less good than students and teachers, and lack of coaching from the local cooperative office. 2) There are two strategies as a solution, i.e., an internal strategy which is the policy of school leadership to support the establishment of sharia-based school cooperatives; And external strategies that should be carried out by the government to support and develop sharia cooperatives including sharia-based school cooperatives.
\end{abstract}

Keywords: Cooperative, School, Sharia based.

\section{A. INTRODUCTION}

The cooperative as an economic organization (Mändle, 2013) that is owned and operated for the common interest is based on the principle of people's economic movement (Bello, 2005) based on the principle of kinship (McNamara, \& Henrich, 2016). When viewed from the aspect of the principle and the purpose of cooperatives that cooperatives are based on the principle of kinship and aims to improve the welfare of members in particular and society in general, as well as an integral part of the order of the national economy which democratic and fair (Alvard, 2009). It is as a place of joint effort in accordance with the character and character of the Indonesian nation in the face of the increasingly dynamic and challenging national and global economic development (Cf., Dobbs, Manyika, Roxburgh \& Lund, 2012). 
Thus, the cooperative has a very strategic role in the national economic order based on the principles of kinship and economic democracy (Chotijah, 2015) to create a developed, just and prosperous society based on Pancasila and the Constitution of the Republic of Indonesia 1945. Therefore, the cooperative should be introduced to every Indonesian citizen, not with the exception to the students. Because the cooperative is a pillar of populist economy in Indonesia (Suhardin \& Siahaan, 2014).

One form of cooperative education in schools to students is the establishment of student cooperatives in schools (Haddara \& Skanes, 2007). This is in order to support student education and cooperative training. Thus, the goal of establishing a school cooperative cannot be separated from the educational objectives and government programs in instilling cooperative awareness early on (Cf., Leithwood, Louis, Anderson and Wahlstrom, 2004).

On the one aspect, the development of sharia financial institutions is currently very booming in Indonesia, but on the other aspect the phenomenon of school cooperatives to date still operate using conventional system, which is still using the concept of interest. Based on the fatwa MUI number 1 of 2004 concerning bank interest states that: 1) The practice of interest has met the criteria of usury that occurred in the time of the Prophet PBUH, namely usury nasi'a. It is therefore prohibited in Islam; 2) The practice of legal interest is haram, whether done by Bank, Insurance, Capital Market, Pawnshop, Cooperative, or other financial institution.

Understanding of sharia economy should be instilled early to support the growth of sharia finance industry (Warde, 2000). So far, Islamic economics has been widely introduced at the college level, while the level of secondary school is still low (Cf., Khatun, 2015; Sabir \& Nasir, 2011). In Indonesia, sharia economic education in secondary schools (Cf., Darmadji, Zubaidah, Sibly \& Andriansyah, 2015) was formally as a local content (Cf., Athoillah, 2015) and taught first in Tasikmalaya City in 2002.

This is as one of the implementation of Regional Regulation (PERDA [Peraturan Daerah]) Tasikmalaya City No.07 / 2014 on Values of Religious Life of Society. In chapter 11, verse 3 mentioned that in carrying out economic activities for every Muslim: a). Prioritizing the sharia economic system; B). Prohibited from practicing usury and / or bonds; And c). In conducting business financing, preferably apply the sharia economic system.

The problem in this research is formulated as follows: 1) what factors become problem so that school cooperative still not become sharia based school cooperative? 2) How is the strategy to realize sharia cooperative in school?

\section{B. METHODS}

This research is applying qualitative approach with the help of Analytic Network Process (ANP) method. 
Research steps:

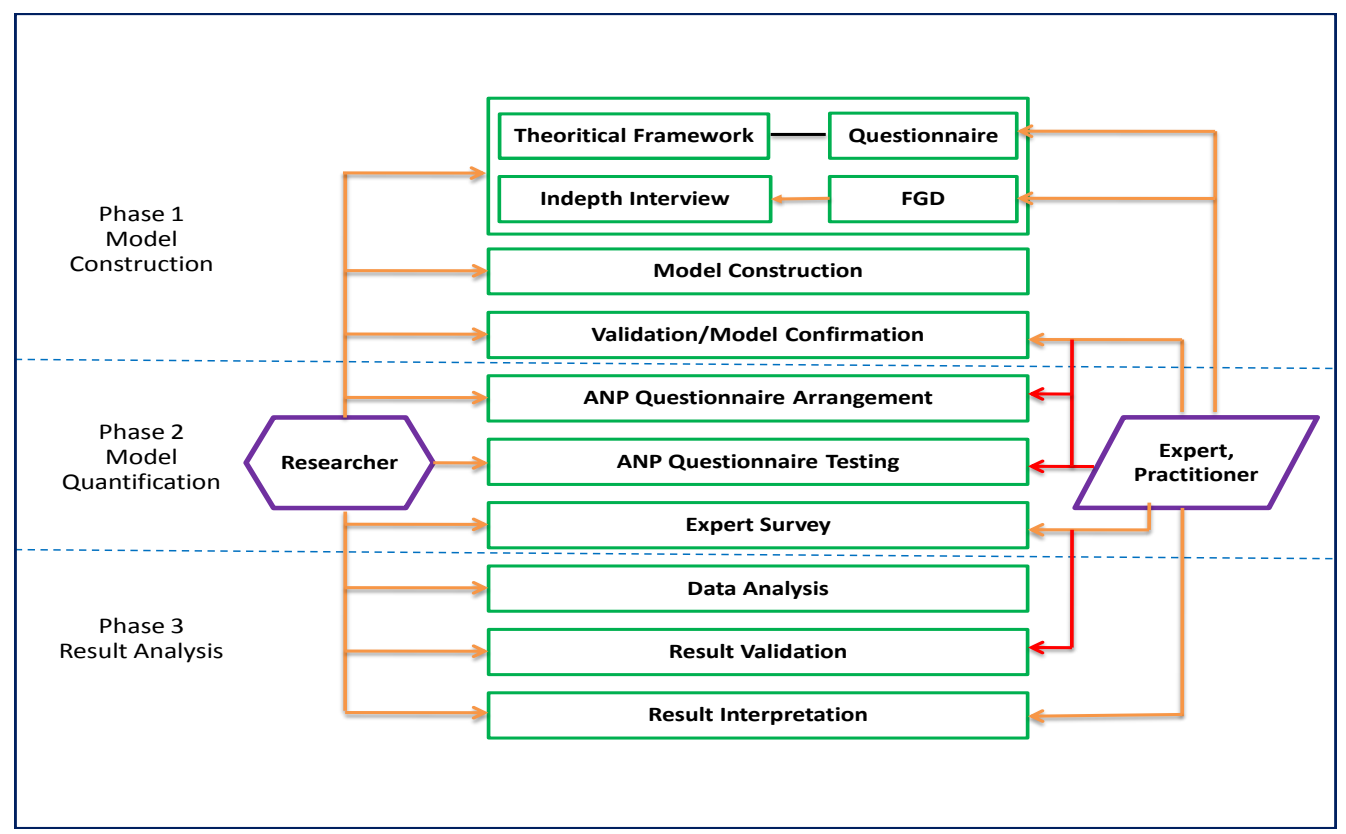

Source: Ascarya, 2009; Cf; Suryanto \& Nasution, 2015

\section{Data Source}

Sources of data in this study is the primary data in the form of respondents, i.e. head of regional office of cooperative and the SMEs, head of regional office of education, 2 persons from academician and 10 persons of teachers and 10 persons of students from high school in Tasikmalaya. The selection of the respondents based on consideration about respondents' understanding on problems faced by the school in implementation of Islamic principles on school cooperative in Tasikmalaya.

\section{Data Collection}

In ANP method, collecting research data is using two ways, the first step is interview and the second step is distributing questionnaire. Questions in the ANP questionnaire are pairwise comparison between elements in the cluster to find out which of them is greater (more dominant) and how big the difference is seen from one side. The scale used is a numerical scale of 1-9 to quantify the verbal assessment of respondents.

\section{Data Analysis Technique}

a. Construction of Model. The ANP model constructs are based on theoretical and empirical review literature and provide questions to school cooperative experts and practitioners and through indepth interviews to review information more deeply about Sharia-based school cooperatives to obtain real problems.

b. Quantification of Model. The model quantification stage uses the question in the ANP questionnaire in the form of pairwise comparison between the elements in the cluster to find out which of the two is the greater the influence (more dominant) and how big the difference is through the numerical scale 1-9. The result data is then collected and 
inputted through super decision software to be processed to produce output in the form of priority and supermatriks.

c. Synthesis and Analysis by calculating geometric mean and rater agreement

\section{RESULT AND DISCUSSIONS}

\section{Theoretical Framework}

\section{a. Definition and Purpose of School Cooperation}

\section{1) Definition of School Cooperative}

The School Cooperative is a cooperative established in a school environment whose members consist of teachers and students who are guided by the school teachers concerned to instill selfreliance, creative and innovative self-confidence, so that students develop and skilled in entrepreneurship, and to realize Cooperatives in Indonesia. (Lindawati and Suyanto, 2015 \& Nurbudiyani, 2013).

While Suwandi (1992) defines the school cooperative as a cooperative whose members consist of elementary school students, junior high school, upper secondary school, boarding school, and other equivalent educational institutions.

Hindayani (2012) defines the school cooperatives more on the purpose of cooperative education in students, the school cooperative as one effort to cultivate cooperative soul (cooperation) to students who will become the successor of nation and state development.

Actually, the school cooperative as one form of cooperative, in its operation is not different from other cooperatives. If the school cooperative is sharia-based, then the school cooperative is the same as other sharia cooperatives.

According Nirbito, that the vision of school cooperatives is the actualization of school potential in facilitating the existence of schools cooperative as miniatures of cooperative life for students. (Nirbito, 2006)

\section{2) Purpose of Establishment of School Cooperative}

The purpose of establishing a school cooperative is to instill cooperative awareness early on among students with cooperative training. Therefore, the school cooperative becomes a means for students to see the real science and its application in daily life. School cooperatives are also a means to organize, foster tolerance and a sense of kinship. (Hindayani, 2012).

This suggests that the school cooperative as a means of school education toward practical activities, to meet the economic needs of students and develop a sense of responsibility, discipline, confidence, leadership, creativity, and democratic spirit of students who are very useful for the development of the nation and state.

Thus, the existence of cooperative schools has a very important role for students, namely: first, as a business organization that can provide economic benefits and able to improve the welfare of 
students as members. Secondly, as a center of entrepreneurship education that can foster the cadres of the cooperative movement and the Indonesian business world. (Firmansyah, et al., 2012).

\section{3) Characteristics of School Cooperative}

Characteristics of cooperative schools cannot be separated from the purpose of the school cooperative itself. Although school cooperatives still gain recognition as an association in the form of cooperatives, but school cooperatives accentuate education rather than profit. If identified school cooperatives have special characteristics that distinguish from other forms of cooperatives.

As for the special characteristics of schools cooperative are as follows (Parmanto, 2002 \& Nurbudiyani, 2013):

a) The school cooperative is acknowledged as a cooperative in the sense of being adequately registered with the Ministry of Cooperatives and does not need to be a legal entity,

b) Established for teaching and learning activities of students ie cooperative teaching labs in schools,

c) The type of cooperative is a cooperative all-round effort,

d) The members are students from the school concerned,

e) The term of membership is limited.

\section{Sharia Principles in Economic Activities of Cooperatives}

The term of sharia in the context of Islamic law studies more describes the collection of legal norms that are the result of the tasyri process. At a time when the term is used in the discussion of the law to be meaningful "All things that Allah Almighty laid to His servants as a way to gain happiness in the world and the hereafter. (Rosyada, 1996).

Thus, the Sharia of Islam is all the rules that comes from Allah SWT and His Prophet, namely, Muhammad PBUH which is intended for the Muslims as a guide of life. Therefore, the sources of Islamic sharia include the Qur'an, al-Sunnah, and ljtihad. (Yahya \& Fatchurrahman, 1993).

The Qur'an and the Sunnah are the source and guidance for Muslims in acting, whether it be aqidah, worship and muamalah. In muamalah matters, not clearly defined by the texts of the Qur'an and al Sunnah. This is due to the form and type of mu'ämala will develop in accordance with the times, places and social conditions. Therefore, Islamic Sharia gives more patterns, general principles than to give explanations about the type and form of mu'āmala in detail. (Haroen, 2000)

Based on the results of induction of the scholars against the Qur'an and al Sunnah about mu'àmala, then made a general rule about mu'āmala that the law of origin something is permissible so there are propositions that forbid it. (Usman, 1997).

When a new transaction emerges, and is not previously known in Islamic law, it is considered acceptable unless there is a Qur'anic or al-Sunnah prohibition which prohibits it either implicitly or explicitly. Thus, an economic or non-economic activity is prohibited for the following reasons: (1) haram substance, (2) haram in addition to its substance, and (3) unauthorized (incomplete) both from the aspect of principium and requisite. (Muhamad, 2013). 
There are some basic rules in fiqh that can be used to be general guidelines for sharia cooperative practice, namely:

a. Basically, every form of mu'āmala is permissible unless there is a prohibition that prohibits it both in al Qur'an and al Sunnah,

b. Only Allah has the right to prohibit and justify everything, as for man only has the right to ijtihād,

c. Something that is unclean and destructive of human dignity and environment is haram,

d. Something that causes to the haram is haram,

e. Purpose or goodwill cannot make the haram become halal,

f. Halal and haram apply to every Muslim who is intelligent and independent,

g. The need to determine the priority scale in decision-making, i.e. 1) avoiding damage takes precedence over taking goodness; 2) social and broad interests are preferred over narrow personal interests; 3 ) small benefits can be sacrificed for greater benefits; 4) avoidance Hazards with larger scales are preferred over hazards on a small scale. (P3EI UII Team, 2008).

In line with the rules of fiqhiyah, the general rules governing economic activities in the Quran and al Sunnah are implemented on the basis of the doctrine of justice. This doctrine is based on the prohibition of usury (interest), gharar (uncertainty), and qimār (gambling), and ta'āwun (mutual cooperation). (Tabari, 2010).

In Islam, cooperatives are classified as syirka / cooperation. This institution is a forum of partnership, cooperation, kinship, and healthy business togetherness, good and halal. Therefore, sharia principles in business either in the form of goods or services of financial institutions must have the following criteria: 1) halal in substances and properties and processes or ways, 2) anti maysir (gambling), 3) anti gharar (manipulation), 4) anti riba' (interest).

While Ascarya (2012) states that the principles of Islamic Economics can be summarized in 5 things: 1) abstain from wasteful and luxurious living, 2) permissible conduct, 3) implementation of zakat, 4) prohibition of riba, and 5) prohibition of gambling (maysir).

Sharia cooperative activities as a microfinance institution should reflect the implementation of Islamic economic principles, both in the collection of funds, funds distribution, and business. Therefore, it is imperative to apply the following principles of sharia:

a. Collect funds from the public in the form of savings which include: savings based on wad̦īa or muḍāraba principle.

b. Distribution of funds through: 1) sale and purchase transactions based on sharia principles such as murabaḥa, istișnā', ijāra, salam, and other buying and selling; 2) revenue-sharing financing based on the muḍāraba principle, mushāraka, and other revenue sharing; 3 ) other financing based on the principle of a) hịāla; b) wakāla; c) 'ujr, d) kafāla.

There are 3 (three) cooperative principles (LKS [Lembaga Keuangan Sharia/Sharia Financial Institution]) in carrying out its business, namely: (1) profit sharing system, the system covering the sharing of business procedures between fund providers and managers; (2) system of sale and purchase with profit margin, which is a system that apply the procedure of buying and selling; (3) fee system (services) (Suryanto, 2015). 


\section{Internal Problems in Sharia-based School Cooperatives}

The main problems dealt by the school to implementative of Islamic principles on school cooperative in Tasikmalaya, are as follow: First, Lack of student participation as caretaker, and member because of learning task. Second, There is still limited capital and infrastructure to establish sharia cooperatives in schools. Third, Has not had knowledge of sharia cooperatives either from students as administrators and teachers as counselors. Fourth, Sharia cooperatives in the students 'and teachers' understanding are identical with financing, thus causing the students to be less interested in sharia cooperatives. Fifth, non-member students prefer shopping to stores outside of school due to price factors.

The internal problems actually relate to two things, namely the ability of students and teachers in understanding of sharia-based school cooperatives and managing the time of the students between learning tasks and extra-curricular activities, namely the school cooperative. And their understanding of the benefits of school cooperatives, especially sharia-based cooperatives. So that it becomes an obstacle in implementing the principles of sharia in the school cooperative. Another issue is related to school policy in providing support to students in utilizing school cooperatives and fund mobilization.

\section{External Problems in Sharia-based School Cooperatives}

External problems first arise from regional office of cooperative and the SMEs. That is to say Lack of guidance to schools from the local cooperative office. Tasikmalaya City Government through the Office of Cooperatives has actually done coaching to schools in the city of Tasikmalaya about the school cooperative, but the activity is only held once a year. This is not enough to foster the spirit of students to cooperate.

The second problem arises from shops outside the school, which is a competition outside the school retail business. They sell students' schooling needs. Therefore, it should be seriously anticipated by the school, because it will inhibit the growth of schools cooperative, especially sharia-based school cooperatives.

\section{Strategy to realize sharia-based school cooperatives}

The strategy as a solution of the problems faced in realizing sharia-based school cooperatives is as follows:

\section{a. The internal strategy from the school}

The role of school leadership in establishing sharia-based school cooperatives is enormous. The authority possessed allows for the birth of sharia-based school cooperatives. The level of adherence of students is very large when the order is born from the school leadership, as long as the policy or order does not conflict with existing rules. If the policy has been issued, the next step is the command to utilize the sharia cooperative that has been formed, accompanied by intensive supervision through cooperative coach appointed by the school leadership, so that this sharia cooperative can survive and develop.

Policy of school leadership to support the realization of sharia-based school cooperatives. This can be done by doing several things, i.e: 
1. Advise students to establish and utilize sharia-based school cooperatives,

2. Building the soul of entrepreneurship of students by sharia through entrepreneurship trainings based on Islamic values,

3. Facilitate socialization and guidance to students and teachers about Sharia-based school cooperatives

4. Empower non-student human resources to assist the operational of sharia-based school cooperatives,

5. Prioritize retail trade based on Islamic values to meet students' schooling needs.

\section{b. The external strategy from the goverment}

The strategy that should be done by the government can be done through the regional office of education and the regional office of cooperative and the SMEs are as follows:

1. To providing training and coaching to students and teachers in schools about sharia cooperatives,

2. The government needs to make policies that can encourage the growth of sharia cooperatives including sharia-based school cooperatives.

\section{CONCLUSION}

Factors that become problem so that school cooperative still not become sharia-based school cooperative is as follows: 1) Lack of student participation as caretaker of school cooperative, 2) Limited capital and infrastructure, 3) Lack of knowledge about sharia cooperatives from both students and teachers, 4) Lack of guidance from the local cooperative office. The strategy as a solution of the problems faced in realizing sharia-based school cooperatives is as follows: 1) The internal strategy of the school leadership policy for support the realization of sharia-based school cooperatives; 2) External strategy in the form of policies from the government to support and develop sharia cooperatives including sharia-based school cooperatives. 


\section{References}

Alvard, Michael. (2009). "Kinship and Cooperation: The Axe Fight Revisited". Hum Nat, 20, pp. 394-416, https://dex.doi.org/10.1007/s12110-009-9074-4

Ascarya. (2009). Analytic Network Process (ANP): Pendekatan Baru Studi Kualitatif. Jakarta : Pusat Pendidikan dan Studi Kebanksentralan, Bank Indonesia.

Ascarya. (2012). Akad dan Produk Bank Sharia. Jakarta: Raja Grafindo Persada.

Athoillah, Mohamad Anton. (2015). Zakat dan Kemiskinan: Analisis Data Panel pada Enam Provinsi di Pulau Jawa, Dissertation, Program Doktor Ilmu Ekonomi, Fakultas Ekonomi \& Bisnis Univesitas Padjadjaran, Bandung.

Bello, Dogarawa Ahmad. (2005). "The Role of Cooperative Societies in Economic Development", Munich Personal RePEc Archive, Online at http://mpra.ub.uni-muenchen.de/23161/ MPRA Paper No. 23161, posted 9. June 2010 03:12 UTC.

Chotijah, Gatyt Sari. (2015). "Reconstructing Indonesian Economic System Based on Legal State Principle of Pancasila". South East Asia Journal of Contemporary Business, Economics and Law, Vol. 7, Issue 3, pp. 23-29.

Darmadji, Ahmad; Zubaidah Syarief; Sibly, M. Roem \& Andriansyah, Yuli. (2015). "Islamic Education Teachers' Content Knowledge of Islamic Law Matters: A Study in Yogyakarta City". Mediterranean Journal of Social Sciences, Vol. 6 No. 5, pp. 441-449 https://dx.doi.org/10.5901/mjss.2015.v6n5p441

Firmansyah, Herlan, et. al. (2012). Advanced Learning Economics. Bandung: Grafindo Media Pratama.

Haddara, Mahmoud \& Skanes, Heather. (2007). "A reflection on cooperative education: from experience to experiential learning". Asia-Pacific Journal of Cooperative Education, 8(1), pp. 67-76.

Haroen, Nasrun. (2000). Fiqh Muamalah, Jakarta: Gaya Media Pratama.

Hindayani, Anik. (2012). "Strategi Peningkatan Partisipasi Siswa dalam Berkoperasi di SMK Negeri 1 Pati". Economic Education Analysis Journal, Semarang: Universitas Negeri Semarang, Vol. 1 No. 1. pp. 1-7.

Warde, Ibrahim. (2000). Islamic Finance in the Global Economy, Edinburgh University Press.

lin Nurbudiyani, lin. (2013). "Pengembangan Model Kewirausahaan SMK Melalui Koperasi Sekolah". Anterior Jurnal, Volume 12 Nomor 2, Juni 2013, pp. 46 - 53.

Khatun, Razia. (2015). "Education of Islamic Economics: An Overview". International Journal of Humanities \& Social Science Studies (IJHSSS), Volume-I, Issue-VI, May 2015, pp. 47-53. 
Leithwood, Kenneth; Louis, Karen Seashore; Anderson, Stephen \& Wahlstrom, Kyla. (2004). Review of research How leadership influences student learning, University of Minnesota Center for Applied Research and Educational Improvement University of Toronto Ontario Institute for Studies in Education Commissioned by The Wallace Foundation.

Lindawati, lilis. et. al. (2015). "Peran Koperasi Sekolah dalam Meningkatkan Sikap Kewirausahaan Siswa SMK Negeri 1 Wonogiri”. Harmoni Sosial: Jurnal Pendidikan IPS Volume 2, No 2, pp. 170-180.

Mändle, Markus. (2013). “The Economics of Housing Co-Operatives Externalities'. the International Journal of Co-Operative Management, Volume 6 Number 2, pp. 25-32.

McNamara, R.A. \& Henrich, J., (2016). "Kin and Kinship Psychology both influence cooperative coordination in Yasawa, Fiji", accepted manuscript in Evolution and Human Behavior https://dx.doi.org/10.1016/j.evolhumbehav.2016.09.004

Muhamad. (2013). Manajemen Keuangan Sharia Analisis Fiqh dan Keuangan. Yogyakarta: STIES.

Nirbito, J.G. (2006). Permasalahan dan Strategi Pemecahan Masalah Pembelajaran Koperasi di Sekolah, Paper presented at Diklat Guru Mata Pelajaran Ekonomi SMA, organized by PPPG IPS \& PMP.

P3EI UII Team. (2008). Ekonomi Islam. Yogyakarta: P3EI UII.

Parmanto. (2002). Kajian Hukum Terhadap Eksistensi Koperasi Sekolah Sebagai Bentuk Khusus Unit Ekonomi Dalam Peningkatan Kualitas Pendidikan, Thesis, Pascasarjana IImu Hukum Universitas Diponegoro. Semarang.

Regional Regulation (Peraturan Daerah Kota Tasikmalaya Nomor 7 Tahun 2014 tentang Tata Nilai Kehidupan Masyarakat yang Relijius di Kota Tasikmalaya).

Rosyada, Dede, (1996). Hukum Islam dan Pranata Sosial, Jakarta: Raja Grafindo Persada.

Sabir A.R \& A. Nasir. (2011). "Teaching Of Islamic Studies As A Subject In The Secondary Schools And Madaris Pakistan". Bi-Annual Research Journal "Balochistan Review", Balochistan Study Centre, Uob, Quetta Vol. Xxiv No.1,

Suhardin, Yohanes \& Siahaan, Rudy Haposan. (2014). "Populist Economy in The State of Welfare Law of Indonesia". International Journal of Business, Economics and Law, Vol. 5, Issue 4, pp. 76-81.

Suryanto, Asep \& Nasution, Fatimah Zahra. (2015). "Analytic Network Process on Financial Access of the Small and Medium Enterprise in Sharia Banking in Tasikmalaya City". International Journal of Nusantara Islam, Vol. 03 No. 02. pp. 19-26. https://dx.doi.org/10.15575/ijni.v3i2.1381

Suryanto, Asep. (2015). "Pemberdayaan Ekonomi Masjid Berbasis Koperasi Sharia", paper presented at Workshop Pemberdayaan Ekonomi Masjid di MUI Desa Cijulang. 
Suwardi, Ima. (1992). Seluk Beluk Koperasi Madrasah Dan Pondok Pesantren, Jakarta, Karya Aksara.

Tabari, Nima Mersadi. (2010). "Islamic Finance and the Modern World: The Legal Principles Governing Islamic Finance". International TradeThe Company Lawyer, Vol. 31, No. 8, pp. 249-254.

Usman, Muhlish. (1997). Kaidah-Kaidah Istinbath Hukum Islam. Jakarta: Raja Grafindo Persada.

Yahya, Mukhtar dan Fatchurrahman. (1993). Dasar-Dasar Pembinaan Hukum Islam, Bandung, AlMa'arif. 
The Strategy of Realizing Sharia Based School Cooperative in Tasikmalaya City, Indonesia 